\title{
FLUIDISED BED COMBUSTION OF TWO SPECIES OF ENERGY CROPS
}

\author{
P. Abelha, C. Franco, H. Lopes, I. Gulyurtlu, I. Cabrita \\ INETI-DEECA, Est. Paço Lumiar, 22, 1649-038 Lisboa, Portugal
}

\begin{abstract}
The use of biomass fuels for energy production through combustion has a growing application worldwide mainly for two reasons: first, the utilization of biomass for energy contributes to mitigate emission of green house gases; second, its use decreases the dependence of imported fossil fuels in Europe. The objective of this work was to study the combustion behaviour of two endogenous biomass species: cardoon (cynara cardunculus) and arundo (arundo donax), which were specially produced in energy crops plantations. Mixtures of cardoon and a forestry biomass specie (eucalyptus) were also studied to evaluate potential benefits from synergies between both biomass fuel types. The results showed that the utilization of cardoon, in pelletized form, and loose arundo as feedstock, did not give rise to any operational problems related with the feeding system. It was verified that the mono combustion of cardoon could pose problems at industrial scale in fluidised bed systems, considering the high levels of $\mathrm{HCl}$ and $\mathrm{NO}_{\mathrm{X}}$ emissions obtained and tendency to sinter the bed sand material. The addition of the forestry biomass to cardoon appeared to prevent the bed agglomeration problem. Furthermore, both the $\mathrm{NO}_{\mathrm{X}}$ and $\mathrm{SO}_{2}$ emissions were found to decrease at the same time suggesting potential synergy of blending different types of biomass regarding pollutant emissions and in bed agglomeration problems.
\end{abstract}

Keywords: energy crops, cynara cardunculus, arundo donax, fluidised bed combustion, gaseous pollutants, biomass

\section{INTRODUCTION}

The use of biomass fuels for energy and/or heat production through combustion processes is becoming extremely attractive worldwide and is being supported by national economic incentives for electricity production from renewable sources, mainly because of two reasons. First, the utilization of biomass contributes to decrease emissions of $\mathrm{CO}_{2}$ due to its renewable nature, although $\mathrm{CO}_{2}$ associated to the production/handling chain must be accounted for. Second, the dependence of imported fossil fuels in Europe could decrease, both because of economical and geo strategic reasons. Biomass has wide potential as energy source in Portugal and other European countries, since significant amounts are generated from forest management activities, from agriculture and agro-industrial activities and municipal solid wastes production. However, experience has shown that the availability of biomass could become a serious barrier for its extensive use for energy due to its seasonal availability and multiple uses. The production biofuels based on energy crop plantations may contribute to diversify the biomass resources and to assure security of supply, particularly for small decentralized installations.

The objective of this work was to study the combustion behaviour, under fluidised bed conditions, of cardoon (cynara cardunculus) and arundo (arundo donax), which were produced in dedicated energy plantations. Mixtures of cardoon and forestry biomass specie, eucalyptus, were also studied to evaluate eventual benefits from synergies of mixing different types of biomass regarding the combustion process, pollutant emissions and ash behaviour that may contribute to decrease environmental and technical impacts of utilization of these energy crops. This work was undertaken in an electrically heated cylindrical lab-scale fluidised bed with $0.08 \mathrm{~m}$ ID and $5 \mathrm{~m}$ height. The bed temperature was around $730{ }^{\circ} \mathrm{C}$, with an excess air varying in the range of 20-50\%. Continuous measurements for $\mathrm{O}_{2}, \mathrm{CO}_{2}, \mathrm{CO}, \mathrm{NO}_{\mathrm{X}}$ and $\mathrm{SO}_{2}$ were carried out in flue gases leaving the combustor and the $\mathrm{HCl}$ content was determined through bubbling combustion gases in a sampling train with impingers, using distilled water as sampling solution. In some runs dolomite was used to evaluate its effects in reducing bed agglomeration tendency and gaseous pollutant emissions. Some interesting results were obtained during the course of this work and are presented below.

\section{EXPERIMENTAL}

\section{Experimental Installation}

The combustor is a bubbling fluidised bed that operates at atmospheric pressure. It is a refractory steel tube, circular in cross-section with an inside diameter of $80 \mathrm{~mm}$ and has $1500 \mathrm{~mm}$ total height. The combustor is located inside an electrical furnace, which provides the heat for fuel ignition and constant combustion 
temperature. The combustor has three independent heating zones which have PID control. Along the reactor, there are various points to measure temperature and pressure.

The fuel is supplied to the combustor above or in-bed, depending on bed height, by a continuous feeding system, composed of a set of two screw feeders. The dosing feeder which is connected to the bottom of the silo was previously calibrated for the mixture to be studied, with the help of an electronic frequency controller. The feedstock in the silo is permanently agitated to avoid blockage, by a mixer connected to the shaft of the screw through two cogwheels. The dosing feeder discharge the fuels to the screw feeder which is connected to the combustor and rotates at a fixed and fast speed in order to avoid the pyrolysis of the feedstock during feeding. In order to avoid the clogging of the tube which could be caused by pyrolysis of the feedstock prior to its entry to the combustor the feeder is externally water cooled. An auxiliary air flow is used to help the waste feeding and to avoid a back flow of the gas.

The combustion/fluidising air is introduced through a gas distributor located in the top of the windbox at the bottom end of the combustor, and secondary air is fed $0.3 \mathrm{~m}$ above bed. The flue gases leave the combustor, passing through a cyclone to remove particles prior to be sampled to on-line $\mathrm{CO}, \mathrm{CO}_{2}, \mathrm{O}_{2}, \mathrm{SO}_{2}$ and $\mathrm{NO}_{\mathrm{x}}$ analysers. The bed material was composed by silica sand particles of $360 \mu \mathrm{m}$ of average diameter. A photograph of the installation is presented in Fig. 1 and in Table 1 the operating conditions are given.

Table 1 Operating conditions

\begin{tabular}{l|c||l|c}
\hline Experimental Parameter & Variation Range & Experimental Parameter & Variation Range \\
\hline Bed temperature $\left({ }^{\circ} \mathrm{C}\right)$ & $730-745$ & Excess air - real $(\%)$ & $25-50$ \\
Flow rate of biomass $(\mathrm{g} / \mathrm{min})$ & $\cong 4.7$ & Primary/secondary air & $70 / 30$ \\
Flow rate of air $(\mathrm{g} / \mathrm{min})$ & $\cong 23.2$ & Pressure & Atmospheric \\
\hline
\end{tabular}

The biomass was supplied in bed under different forms: cardoon was fed in pelletized form (20-30 mm x 5 $\mathrm{mm}$ ); loose arundo and eucalyptus were used milled below $5 \mathrm{~mm}$. The fluidising velocity was between $0.30-0.35 \mathrm{~m} / \mathrm{s}$, depending on the level of excess air. The bed temperature was maintained below $750{ }^{\circ} \mathrm{C}$ to minimize bed agglomeration problems associated with the presence of low melting point ash compounds, containing $\mathrm{Na}$ or $\mathrm{K}$ silicates. The freeboard temperature was imposed by the electric furnace to obtain a similar temperature profile as expected when operating the INETI's pilot installation burning similar biomass materials (Gulyurtlu et al., 2007 and Gulyurtlu et al., 2005) (see Fig. 2).

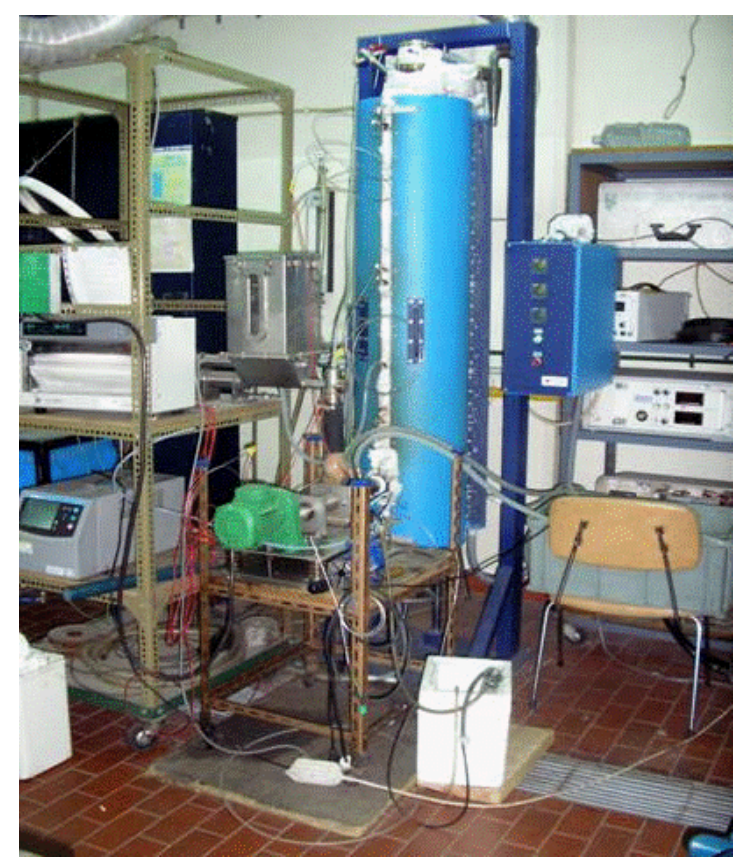

Fig. 1 Bench-scale combustion installation

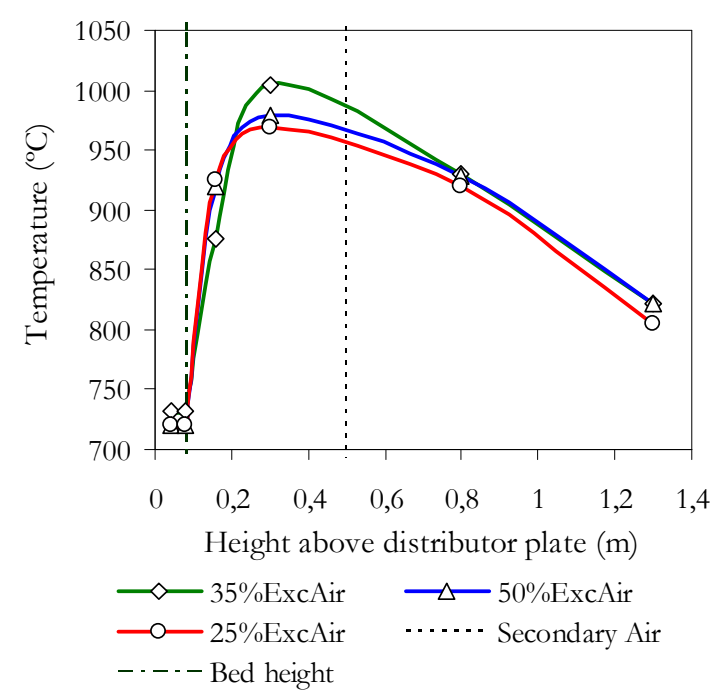

Fig. 2 Effect of excess air in temperature profile for combustion of $100 \%$ cardoon; Tbed $=730^{\circ} \mathrm{C}$

\section{Fuel Characterization}

Analyses of arundo, cardoon and eucalyptus are shown in Table 2. Like any other biomass fuels of similar origin (energy crops), the arundo and cardoon presented significant levels of ash, higher than that of eucalyptus, 
low fixed carbon and high volatile matter and oxygen content. The nitrogen levels of arundo and eucalyptus were relatively low when compared to normal bituminous coals, usually used for energy production (1-2\%). However, special attention should be paid to nitrogen oxide formation during the combustion of cardoon since its nitrogen content reached $1.7 \%$. Sulphur was also detected, in higher amounts in the cardoon, hence the use of adsorbents during its combustion was evaluated to prevent $\mathrm{SO}_{2}$ emissions.

Table 2 Feedstock Analysis (db - dry base)

\begin{tabular}{|c|c|c|c|}
\hline & Arundo & Cardoon & Eucalyptus \\
\hline $\mathrm{HHV}(\mathrm{MJ} / \mathrm{kg} \mathrm{db})$ & 16.74 & 18.84 & 17.12 \\
\hline Moisture (\%) & 8.4 & 13.1 & 9.8 \\
\hline Ash (\% db) & 8.5 & 6.2 & 2.1 \\
\hline Vol. Matter (\% db) & 75.3 & 76.9 & 87.0 \\
\hline Fixed Carbon $(\% \mathrm{db})$ & 16.2 & 16.9 & 10.9 \\
\hline Carbon $(\% \mathrm{db})$ & 45.9 & 49.3 & 52.6 \\
\hline Hydrogen $(\% \mathrm{db})$ & 5.6 & 6.1 & 5.2 \\
\hline Nitrogen $(\% \mathrm{db})$ & 0.7 & 1.7 & 0.3 \\
\hline Sulphur $(\% \mathrm{db})$ & 0.15 & 0.29 & 0.07 \\
\hline Chlorine $(\% \mathrm{db})$ & 0.16 & 0.47 & 0.01 \\
\hline Oxygen \& errors (\% db) & 39.2 & 36.5 & 39.7 \\
\hline $\mathrm{Al}_{2} \mathrm{O}_{3}(\%$ of ash $)$ & 0.44 & 0.80 & 0.32 \\
\hline $\mathrm{CaO}(\%$ of ash $)$ & 2.96 & 10.4 & 49.3 \\
\hline $\mathrm{Fe}_{2} \mathrm{O}_{3}(\%$ of ash $)$ & 0.44 & 1.16 & 5.20 \\
\hline $\mathrm{K}_{2} \mathrm{O}(\%$ of ash $)$ & 21.5 & 13.7 & 14.0 \\
\hline $\mathrm{MgO}$ (\% of ash) & 2.21 & 5.39 & 6.30 \\
\hline $\mathrm{Na}_{2} \mathrm{O}(\%$ of ash $)$ & 1.01 & 21.5 & 3.78 \\
\hline $\mathrm{SiO}_{2}(\%$ of ash $)$ & 54.3 & 15.5 & 1.30 \\
\hline $\mathrm{P}_{2} \mathrm{O}_{5}(\%$ of ash $)$ & 3.82 & 1.92 & 2.40 \\
\hline \multicolumn{4}{|l|}{ Ash Fuzibility (oxidante) } \\
\hline Shrinkage Temperaure & $558^{\circ} \mathrm{C}$ & $549^{\circ} \mathrm{C}$ & - \\
\hline Deformation Temperature & $1010^{\circ} \mathrm{C}$ & $624^{\circ} \mathrm{C}$ & - \\
\hline Hemisphere Temperature & $1114^{\circ} \mathrm{C}$ & $675^{\circ} \mathrm{C}$ & - \\
\hline Flow Temperature & $1257^{\circ} \mathrm{C}$ & $1407^{\circ} \mathrm{C}$ & - \\
\hline
\end{tabular}

Contents of $\mathrm{Cl}$ were found to be much higher in cardoon than in arundo and this may bring environmental problems because of $\mathrm{HCl}$ emissions and operational problems due to corrosion and fouling effects. The eucalyptus may be considered a relatively clean fuel as it presents low content of undesired elements like sulphur, chlorine and alkali metals.

\section{DISCUSSION OF RESULTS}

The arundo and cardoon species were burned individually and the influence of temperature and excess air on their combustion behaviour was studied. The addition of eucalyptus and dolomite was also investigated and correlated with the gas composition and emissions of $\mathrm{HCl}, \mathrm{NO}_{\mathrm{x}}$ and $\mathrm{SO}_{2}$.

\section{Influence of Excess Air}

In Fig. 2 it is presented the temperature profile for different excess air values used during combustion of cardoon. The temperature increase just above the bed, near the feeding point, is due to a higher combustion rate of the volatile fuel fraction that have been rapidly released, increasing the temperature in that zone. On the other hand, the bed operates with less fuel. Consequently, a higher air staging ratio and a more intense mixing between fuel and the air in the freeboard are required for complete combustion.

There is a gradual increase of the maximum temperature when the excess air is raised from 25 to $35 \%$ due to a more complete combustion encouraged by the extra air supplied. However, increasing the excess air to $50 \%$ does not bring about further advantages concerning the combustion efficiency and, in fact, contributes to reducing the temperature by dilution and cooling effects.

In Fig. 3 it can be seen the effect of excess air on the $\mathrm{SO}_{2}$ and $\mathrm{NO}_{\mathrm{X}}$ emissions. The increase of the excess 
air did not appear to influence the $\mathrm{SO}_{2}$ emissions significantly for both arundo and cardoon; however, there was a larger effect on the $\mathrm{NO}_{\mathrm{X}}$ production. For this reason, a compromise should be attained when optimizing the excess air level conditions for efficient combustion and $\mathrm{NO}_{\mathrm{X}}$ formation. During the combustion of cardoon higher levels of $\mathrm{NO}_{\mathrm{X}}$ were produced when compared with arundo combustion. This is probably related with the fact that cardoon has about 2.5 times more nitrogen content. Nevertheless, the $\mathrm{NO}_{\mathrm{X}}$ levels obtained are excessive for both solid biofuels, when compared with typical emissions obtained in fluidised beds. The main reason for this is probably the small scale of the lab reactor, that does not allow much interaction between the $\mathrm{N}$-volatile species (mainly $\mathrm{NH}_{3}$ ) and the formed $\mathrm{NO}_{\mathrm{X}}$, severely limiting the $\mathrm{DeNO}_{\mathrm{X}}$ reduction mechanism found to be essential for $\mathrm{NO}_{\mathrm{X}}$ abatement in biomass combustion, as reported in other works (Abelha et al., 2008).

The emission levels for $\mathrm{SO}_{2}$ are fairly similar for the combustion of both cardoon and arundo and could easily be maintained at low values without addition of adsorbents. This is related with the presence of calcium in the biomass and the molar ratios of $\mathrm{Ca} / \mathrm{S}$, as although $\mathrm{S}$ is higher for cardoon, its $\mathrm{Ca} / \mathrm{S}$ ratio is higher than in the case of arundo.

The concentration of $\mathrm{HCl}$ in the flue gases as a function of excess air is presented in Fig. 4. In the case of cardoon combustion, it seems that a less oxidant atmosphere favoured a slightly higher conversion of $\mathrm{Cl}$ to the gas phase and its emission as $\mathrm{HCl}$. However, for arundo this effect could not be verified, as $\mathrm{HCl}$ was measured only in two runs.

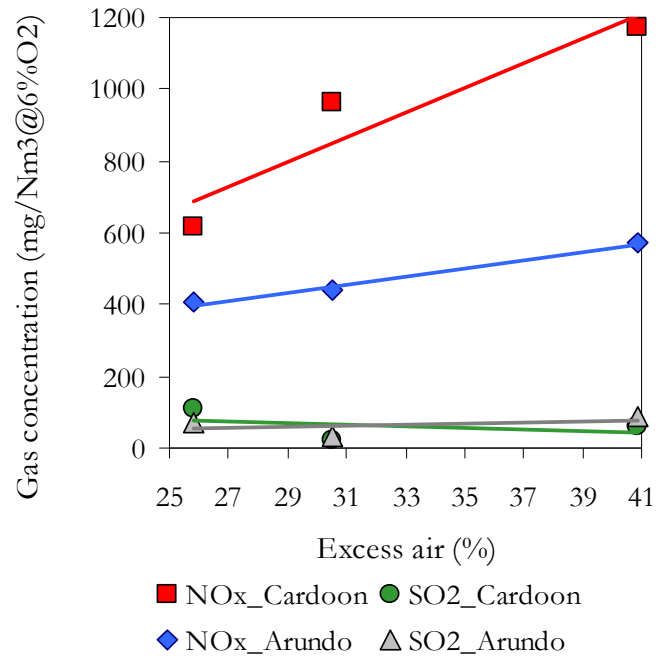

Fig. 3 Effect of excess air in $\mathrm{NO}_{\mathrm{X}}$ and $\mathrm{SO}_{2}$ emissions. Tbed $=730^{\circ} \mathrm{C}$

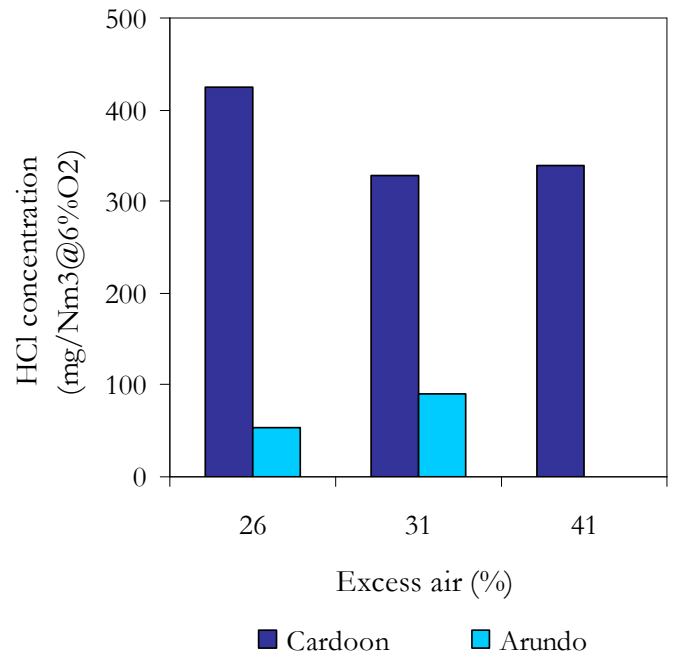

Fig. 4 Effect of excess air on $\mathrm{HCl}$ emissions. For $100 \%$ Cardoon and $100 \%$ Arundo; Tbed $=730^{\circ} \mathrm{C}$

Cardoon has higher $\mathrm{Cl}$ content than arundo, almost 3 times more, and this explains the fact that more $\mathrm{HCl}$ was found in the combustion gases during the combustion of the former. The amount of $\mathrm{HCl}$ present in the combustion gases was found to be between 60 and $75 \%$ of the $\mathrm{Cl}$ fuel input, meaning that part of it could have been retained in the ashes due to the high concentrations of $\mathrm{K}$ and $\mathrm{Na}$. However, alkaline-earth metals may start volatilizing at the operation temperatures utilized, releasing $\mathrm{Cl}$. The $\mathrm{HCl}$ emission levels from the combustion of cardoon are slightly above the Portuguese emission limit values $\left(250 \mathrm{mg} / \mathrm{Nm}^{3} @ 8 \% \mathrm{O}_{2}\right)$ for general industrial processes. This problem should be taken in consideration if cardoon is to be used in industrial plants (Knudsen et al., 2004, Frandsen, 2005).

Although the temperature was maintained below $750^{\circ} \mathrm{C}$ to prevent bed agglomeration, during the combustion of only cardoon or arundo it was detected the formation of some agglomerates of the bed sand plus ashes, which could be related to the presence of high contents of $\mathrm{K}$ and $\mathrm{Na}$ in both biomass fuels (Zevenhoven-Onderwater et al., 2006). This means that over long periods of combustion of these biofuels it might be possible that bed defluidisation occurs because of the accumulation of agglomerates of the bed material. In fluidised bed systems, one possibility to decrease this tendency is to use additives to modify ash behaviour (Zevenhoven-Onderwater et al., 2001). One other option is to mix these problematic fuels with others less problematic to minimize this adverse effect. Hence, it was decided to use eucalyptus as a supporting fuel in several fuel fractions $(0,40,80,100 \% \mathrm{wt})$ to verify its effect in decreasing ash sintering tendency.

In Fig. 5 it is possible to observe that the addition of about $40 \%$ wt of eucalyptus in the fuel input. Although it reduced the effect, it did not completely solve the problem of agglomerate formation. It was necessary to raise the eucalyptus fraction in fuel blend to about $80 \%$ wt to fully avoid any agglomeration (see 
Fig. 6). This way, cardoon became a secondary fuel. If a woody clean biomass fuel is not available in great amounts, the use of a calcium base additive could be another route to reduce ash agglomeration tendency.

Two mixtures of $15 \%$ and $30 \%$ wt dolomite with silica sand were used as bed material, during the combustion of a mixture of $60 \% \mathrm{wt}$ cardoon and $40 \% \mathrm{wt}$ eucalyptus. The formation of agglomerates was totally prevented even with the lower amount of dolomite in the bed, as it can be seen in Fig. 7. The addition of dolomite also effected the pollutant emissions. In Fig. 8 it can be observed the influence of dolomite addition to the bed on the $\mathrm{NO}_{\mathrm{x}}$ and $\mathrm{SO}_{2}$ emissions. As expected, $\mathrm{SO}_{2}$ decreased because dolomite acted as an adsorbent retaining the sulphur in solid phase as sulphates. However, the decrease was supposed to be more effective and the reason for this behaviour is again related to the small scale of the lab reactor, and more precisely with the small bed height (about $0.1 \mathrm{~mm}$ ) that does not allow much interaction and sufficient residence time between the dolomite particles with $\mathrm{SO}_{2}$. Moreover, the temperature was not adequate for the reaction process, being lower than the ideal for the calcination of the dolomite $\left(800-900^{\circ} \mathrm{C}\right)$ (Lyngfelt and Leckner, 1998, Anthony and Granatstein, 2001).

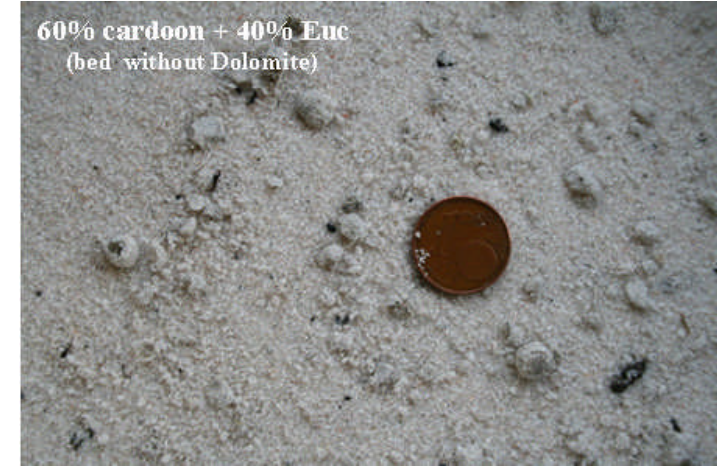

Fig. 5 Small agglomerates formed during combustion of $60 \%$ Cardoon $+40 \%$ Eucalyptus; Tbed $=730^{\circ} \mathrm{C}$



Fig. 6 No agglomerates formed during combustion of $20 \%$ Cardoon $/ 80 \%$ Eucalyptus; Tbed $=730^{\circ} \mathrm{C}$

The dolomite, as well as the limestone and other $\mathrm{Ca}$ based additives, are known to be active catalysts in the formation of $\mathrm{NO}_{\mathrm{X}}$ due to the oxidation of its gaseous precursors (mainly $\mathrm{NH}_{3}$ in the case of biomass), through both homogeneous and heterogeneous mechanism (Amand et al., 1993, Anthony and Lu, 1998, Jensen et al., 1996). This way, it is not surprising the observed increase in NOx emission levels as the share of dolomite in the bed material was greater (see Fig. 8).

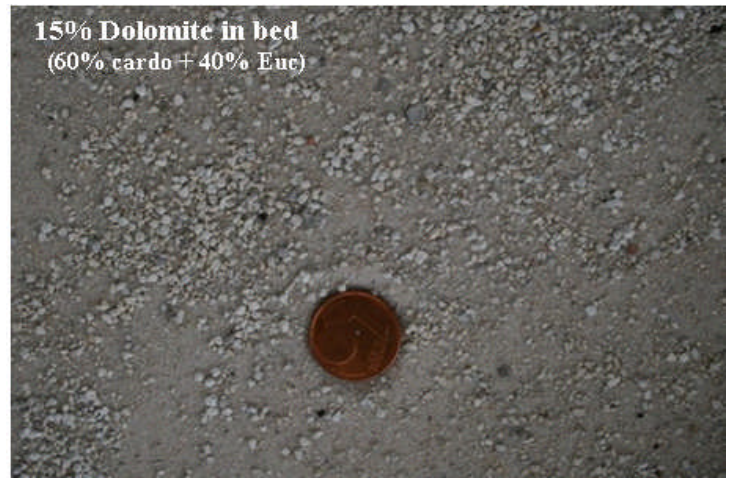

Fig. 7 No agglomerates formed during combustion of $60 \%$ Cardoon $+40 \%$ Eucalyptus, with $15 \%$ wt dolomite in bed. Tbed $=730^{\circ} \mathrm{C}$

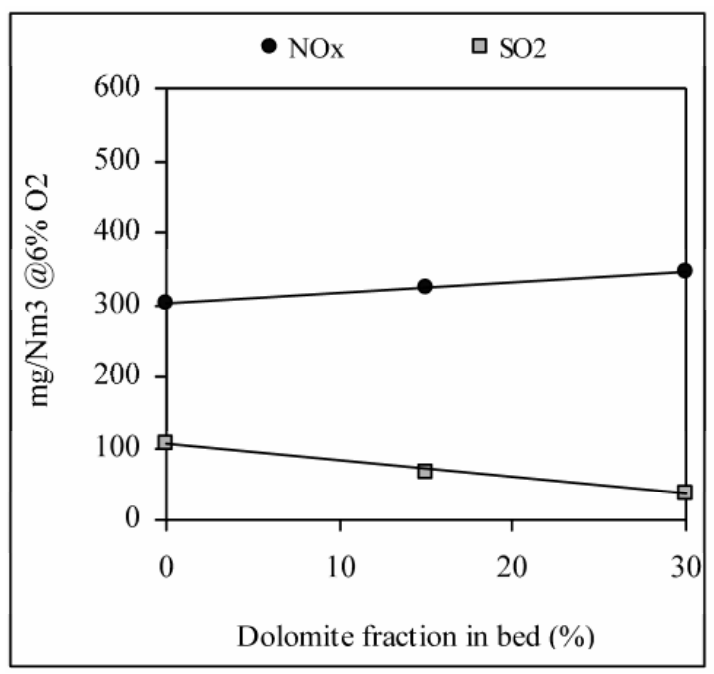

Fig. 8 Effect of dolomite on $\mathrm{NO}_{\mathrm{X}}$ and $\mathrm{SO}_{2}$ emissions. $60 \%$ Cardoon+40\%Eucalyptus; Excess air $=30 \% ; \mathrm{T}=$ $730-745^{\circ} \mathrm{C}$

A more effective way to simultaneously decrease both $\mathrm{NO}_{\mathrm{X}}$ and $\mathrm{SO}_{2}$ emissions from cardoon combustion is to add some clean woody biomass like eucalyptus. In Fig. 9 it is presented the reduction in emissions obtained when supplying up to $80 \%$ wt of eucalyptus to cardoon combustion. It should be expected similar result with adding any other woody biomass instead of eucalyptus, like pinus for example, because such biomass species have very low $\mathrm{N}$ and $\mathrm{S}$ contents. 
The effect of eucalyptus addition to cardoon combustion on the concentration of chlorine was also evaluated and the results are presented in Fig. 10, as a function of the eucalyptus fraction in the mixture. Since the $\mathrm{Cl}$ content of eucalyptus was much lower compared with cardoon, chlorine emissions were lowered when increasing the fraction of the woody biomass in the fuel. The Portuguese legal limit value for $\mathrm{HCl}$ emission was respected for mixtures above $20 \%$ wt of eucalyptus.

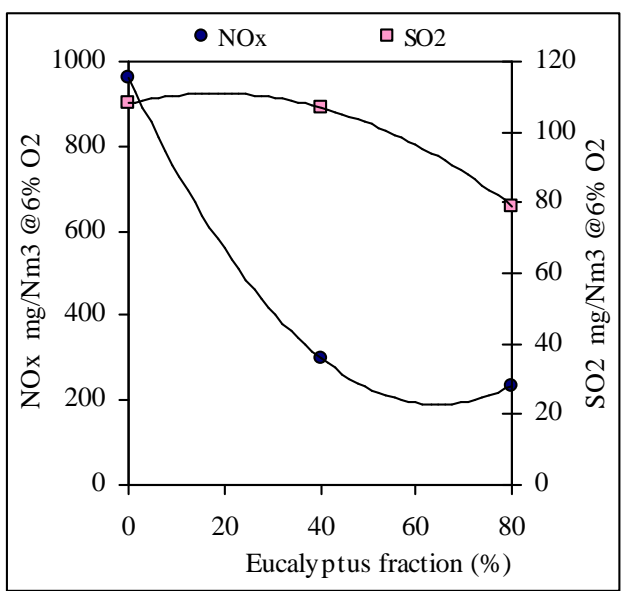

Fig. 9 Effect of eucalyptus fuel fraction increaseon $\mathrm{NO}_{\mathrm{X}}$ and $\mathrm{SO}_{2}$ emissions

Excess air $=30 \% ; \mathrm{T}=730-745^{\circ} \mathrm{C}$



Fig. 10 Effect eucalyptus fuel fraction increase in $\mathrm{HCl}$ emissions Excess air $=30 \% ; \mathrm{T}=730-745^{\circ} \mathrm{C}$

\section{CONCLUSIONS}

Cardoon combustion at industrial level should take into account chlorine content in the fuel since results obtained showed high emission levels, being above the Portuguese limit emission values for general industrial process. The arundo combustion did not give rise to $\mathrm{HCl}$ emissions of too much concern.

High levels of $\mathrm{NO}_{\mathrm{X}}$ were obtained during burning of cardoon and special attention should also be taken in consideration concerning this pollutant, although in industrial fluidised bed, with a more effective temperature, excess air and air staging control, maximization of $\mathrm{DeNO}_{\mathrm{X}}$ mechanism could be accomplished and lower emissions would be expected.

Addition of clean forest biomass, like eucalyptus, to cardoon or arundo during combustion, could enhance environmental benefits by decreasing $\mathrm{SO}_{2}, \mathrm{NO}_{\mathrm{X}}$ and $\mathrm{HCl}$ emissions. Other advantages are the improvement of bed behaviour through decreasing agglomerating tendencies by diluting the presence of alkali elements like $\mathrm{Na}$ and $\mathrm{K}$, and minimizing other problems associated with the low ash fusibility temperatures, like slagging and fouling. Consequently, it could also reduce tendency to corrosion in steam boilers. If the mixture with woody biomass could not be possible, the use of additives like dolomite should also be considered to achieve better bed management and possible control of $\mathrm{SO}_{2}$ and $\mathrm{HCl}$.

\section{REFERENCES}

Abelha, P., Gulyurtlu. I., Cabrita, I.: Energy \& Fuels 22, (2008), pp.363-371.

Åmand, L-E., Leckner, B., Dam-Johansen, K.: Fuel 72 (1993), pp. 557-564.

Anthony, E.J., Granatstein D.L.: Progress in energy and Combustion Science 27 (2001), pp. 215-236.

Anthony, E.J., Lu, Y.: Relationship between $\mathrm{SO}_{2}$ and other pollutant emissions from fluidized-bed combustion. Proc. of the 27th Inter. Symp. on Combustion, The Comb. Institute (1998), pp. 3093-3101.

Frandsen, F. J.: Fuel 84 (2005), pp.1277-1294.

Gulyurtlu, I., Crujeira, A.T., Abelha, P., Cabrita I.: Fuel 86 (2007), pp.2090-2100.

Gulyurtlu, I., Boavida, D., Abelha, P., Lopes, M.H., Cabrita, I.: Fuel 84 (2005), pp. 2137-2148.

Jensen, A., Johnsson J.E., Dam-Johansen. K. Nitrogen chemistry in FBC with limestone addition. Proc. 26th Int. Symposium on Combustion. The Comb. Institute (1996), pp 3335-3342.

Knudsen, J. N., Jensen, P. A, Dam-Johansen, K. Quantification of the Release of Cl, K and S to the gas Phase from Combustion of Annual Biomass. Proceedings of the $2^{\text {nd }}$ World Conference and Technology Exhibition on Biomass for Energy, Industry and Climate Protection, (2004), paper ref. OD4.2.

Lyngfelt, A., Leckner,. B.: Journal of the Institute of Energy 71 (1998), pp. 27-32.

Zevenhoven-Onderwater, M., Ohman, M., Skrifvars B.-J, Backman, R., Nordin, A., Hupa, M.: Energy \& Fuels 20 (2006), pp. 818-824.

Zevenhoven-Onderwater, M., Backman, R., Skrifvars, B.-J. Hupa M.: Fuel 80, (2001), pp. 1489-1502. 